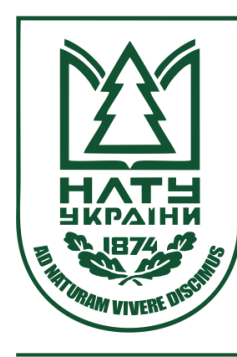

Науковий вісник НЛТУ України Scientific Bulletin of UNFU

http://nv.nltu.edu.ua

https://doi.org/10.15421/40290108

$@ \bowtie$ Correspondence author

Article received 13.02.2019 p.

Article accepted 28.02.2019 p.

L. P. Stepanenko

удк 630*54(477.41)

I.stepanenko15@ukr.net

Л. П. Степаненко

ВП НУБіП Украйни "Боярський коледж екології і природних ресурсів", м. Боярка, Украӥна

\title{
ДИНАМІКА БІОПРОДУКТИВНОСТІ ЛІСІВ КИЇВСЬКОЇ ОБЛАСТІ
}

Наведено результати моделювання компонентів фітомаси головних лісотвірних порід Київської обл. Встановлено, що від основних таксаційних ознак насаджень, які вказують у даних лісового кадастру, залежить принцип побудови моделей оцінки біопродуктивності деревостанів головних лісотвірних порід області за компонентами надземної фітомаси, який полягав у встановленні їх багатофакторних залежностей. Регресійний аналіз засвідчив, що найпридатніша 3 точки зору точності та практичності застосування є двофакторна модель залежності основних компонентів фітомаси насадження, в якій як фактори задіяні вік насадження та клас бонітету. Насадження Київської обл. розташовані у двох лісорослинних зонах. Під час аналізу визначено позитивну динаміку кількісних показників збільшення щільності фітомаси та вуглецю в насадженнях Київської обл., яка зросла відповідно на 8,4-4,2 кг· $\left(\mathrm{M}^{2}\right)^{-1}$. За досліджуваний період відбулося збільшення фітомаси в 1,6 раза. Відповідно в лісорослинних зонах Полісся та Лісостепу в 1,4-2,1 раза. Лісові насадження мають великий вплив на формування навколишнього середовища і здатні впливати на такі фактори, як температура і вологість повітря на планеті. Роль лісу неможливо оцінити як щось однозначне, оскільки цей ресурс використовують у різноманітних галузях виробництва. Тому насадження Київської обл. мають важливе економічне, екологічне та соціальне значення, виконують важливі захисні та охоронні функції і є високопродуктивними.

Ключові слова: деревостан; середній запас; лісистість; лісорослинні зони; щільність фітомаси; щільність вуглецю; конверсійні коефіціснти.

Вступ. Майже вся територія України є зоною екологічного лиха, що законодавчо закріплено рішеннями Верховної Ради України. Зважаючи на принцип рівноправності та право кожного народу самостійно вирішувати свою долю, Україна, поряд з визначенням свого внутрішнього і зовнішнього статусу, напрямків політичного, економічного, соціального та культурного розвитку, мусить обов'язково опрацювати стратегію і тактику порятунку від глибокої екологічної кризи, віднайти шляхи забезпечення екологічного благополуччя країни, збереження національних природних ресурсів для майбутніх поколінь.

Діяльність у галузі лісового господарства є одним 3 важливих напрямів боротьби зі зміною клімату. За оцінками Міжурядової групи експертів зі зміни клімату, близько $20 \%$ поточного збільшення концентрації парникових газів зумовлено змінами в землекористуванні і передусім вирубуванням лісів, що супроводжується втратою накопиченого в поглиначів оксидів вуглецю 3 атмосфери та вагомих акумуляторів органічних сполук вуглецю, тому вивчення біопродуктивності лісів Київської обл. $є$ актуальним.

Моделювання компонентів фітомаси насаджень основних лісотвірних порід Київської обл. здійснювали шляхом встановлення одно- та багатофакторних залежностей компонентів фітомаси від таксаційних ознак насаджень, які вказують у даних лісового кадастру. Подібний метод розроблення нормативів оцінки компонентів фітомаси насаджень використовували у своїх дослідженнях П. І. Лакида (Lakida, 1988, 1990, 1996; Lakyda, et al., 2007, 2010), В. А. Усольцев (Usoltcev, 1984, 1985a, 1985b), D. B. Botkin, L. G. Simpson (Botkin \& Simpson, 1990), H. A.I. Madgwick (Madgwick, 1970), T. Satto, H. A.I. Madgwick (Satto \& Madgwick, 1982) та інші науковці.

Матеріал і методи дослідження. Для розрахунку алгоритму фітомаси деревостанів та депонованого вуглецю Київської обл. зібрано дані Державного лісового кадастру на 1.01.1978 р., 1.01 .1983 р., 1.01 .1988 р., 1.01.1996 р., 1.01.2002 р. та 1.01.2011 р. для державних підприємств лісового господарства області та загалом у межах ДАЛР України.

Для інформаційного забезпечення моделювання оцінки і прогнозу динаміки компонентів фітомаси деревостанів Київської обл., дослідними даними слугували результати таксації 63 ТПП, закладених науковими співробітниками кафедри таксації лісу та лісового менеджменту Національного університету біоресурсів i природокористування України. Основним завданням під час використання даних ТПП $є$ встановлення взаємозв'язку між таксаційними показниками і фітомасою лісових насаджень. Тому, встановивши закономірність взаємозв'язку вагових характеристик фітомаси і таксаційних показників, можна дати коректну оцінку запасів фітомаси лісів на території Київської обл.

Залежною змінною під час моделювання динаміки фітомаси деревостану від таксаційних показників використовували конверсійні коефіцієнти $\left(R_{V}\right)$, тобто відно-

Інформація про авторів:

Степаненко Людмила Петрівна, здобувач, кафедра таксації лісу та лісового менеджменту. Email: I.stepanenko15@ukr.net

Цитування за ДСту: Степаненко Л. П. Динаміка біопродуктивності лісів Київської області. Науковий вісник Нлту України. 2019, т. 29, № 1. С. 41-44.

Citation APA: Stepanenko, L. P. (2019). Dynamics of Forest Bioproductivity in the Kyiv Region. Scientific Bulletin of UNFU, $29(1), 41-44$. https://doi.org/10.15421/40290108 
шення маси фракції фітомаси $\left(M_{f r}\right)$ до запасу стовбура в корі $(M)$ :

$$
R_{v}=M_{r} / M
$$

Щільність фітомаси та вуглецю, а також його запас розраховували на ПК за допомогою калькуляційної програми CARBON (Lakyda, 1996). Для аналізу і моделювання прийнято такий поділ фітомаси насаджень за фракціями: деревина і кора стовбурів; деревина і кора гілок; листя (хвоя); деревина і кора пнів та коренів; піднаметова рослинність.

Результати дослідження. 3 використанням залежності зі загальним виглядом здійснювали пошук математичних моделей взаємозв'язку конверсійних коефіцієнтів насаджень регіону дослідження із загальною фітомасою насаджень:

$$
R v=f(A, E, \Pi)
$$

де: $R_{v}$ - відповідні конверсійні коефіцієнти (деревина, кора, листя (хвоя) тощо); $f(A, \bar{L}, \Pi)$ - функції таксаційних ознак деревостану (вік, бонітет, повнота).

Регресійний аналіз робочих масивів даних, які складаються з коефіцієнтів відношень компонентів фітомаси і таксаційних ознак насаджень у межах деревної породи, показав, що на динаміку коефіцієнтів $R_{V}$ значуще (5\%-й рівень) впливають всі перелічені вище таксаційні показники. Тому, враховуючи вагомість кожного 3 перелічених показників та можливість адаптації в розрахунках отриманих рівнянь і статистичних параметрів розподілу лісового фонду країни, основними аргументами моделей $R_{V}$ прийнято середній вік $(A)$ та клас бонітету $(Б)$ насадження. Характеристику параметрів рівнянь коефіцієнтів відношень $R_{V}$ фракцій фітомаси у насадженнях Київської обл. наведено в табл. 1.

Проаналізувавши коефіцієнти рівнянь, можна зробити висновки, що всі досліджувані компоненти фітомаси насаджень граба звичайного описуються регресійними рівняннями 3 високим рівнем апроксимації. Для сосни звичайної, дуба звичайного та вільхи клейкої характеризуються рівняння множинними кореляційними відношеннями, дещо нижчими, але значущими на $5 \%$-у рівні. Для гілок у корі та листя берези повислої коефіцієнти детермінації та інші статистичні показники виявилися незначущими, тому в подальших розрахунках використовували їх середні значення.

Фітомасу піднаметової рослинності та підземну фітомасу деревостанів головних лісотвірних порід Київської обл. не визначали під час проведення досліджень біопродуктивності лісів, тому було використано множинні регресійні рівняння конверсійних коефіцієнтів, отримані П. І. Лакидою (Lakida, 1996).

Було розраховано загальні обсяги фітомаси та вуглецю в лісах Київської обл., підпорядкованих Державному агентству лісових ресурсів України за роками досліджень та групами лісотвірних порід, на основі розроблених моделей та даних лісового кадастру.

Табл. 1. Множинні регресійні рівняння конверсійних

\begin{tabular}{|c|c|c|c|}
\hline Модель регресії & $R^{2}$ & Модель регресії & $R^{2}$ \\
\hline \multicolumn{2}{|l|}{ Сосна звичайна } & \multicolumn{2}{|l|}{ Дуб звичайний } \\
\hline$R_{v}(s t)^{*}=0,323 \cdot A^{0,41} \cdot B^{-0,}$ & 0,32 & $R_{v}(s t)=0,507 \cdot A^{-1}$ & 0,09 \\
\hline$R_{v}(k)=0,096 \cdot A^{-0,280}$ & 0,33 & $R_{v}(k)=0,050 \cdot A^{0,115}$ & 0,13 \\
\hline$R_{v}(g)=1,968 \cdot A^{-0,817}$ & 0,58 & $R_{v}(g)=3,688 \cdot A^{-1,009}$ & 0,60 \\
\hline$R_{v}(l)=0,203 \cdot A^{-0,665}$ & 0,51 & $R_{v}(l)=0,182 \cdot A^{-0,665}$ & 0,22 \\
\hline \multicolumn{2}{|l|}{ Граб звичайний } & \multicolumn{2}{|l|}{ Вільха клейка } \\
\hline$R_{v}(s t)=0,559 \cdot A^{0,019}$ & 0,81 & $R_{v}(s t)=0,39$ & 0,50 \\
\hline$R_{v}(k)=0,084 \cdot A^{-0,245}$ & 0,80 & $R_{v}(k)=0,045 \cdot A^{0,}$ & 0,51 \\
\hline$R_{v}(g)=0,417 \cdot A^{-0,41 T}$ & 0,83 & $R_{v}(g)=0,042 \cdot A^{-0,068}$ & 0,07 \\
\hline$R_{v}(l)=0,092 \cdot A^{-0,444}$ & 0,79 & $R_{v}(l)=0,333 \cdot A^{-t}$ & 0,88 \\
\hline \multicolumn{4}{|c|}{ Береза повисла } \\
\hline \multirow{2}{*}{\multicolumn{3}{|c|}{$\begin{array}{l}R_{v}(s t)=0,372 \cdot A^{0,21} \\
R_{v}(k)=0,074 \cdot A^{-0,198}\end{array}$}} & 0,23 \\
\hline & & & 0,23 \\
\hline \multicolumn{3}{|c|}{$R_{v}(g)$ залежність не встановлена } & \\
\hline \multicolumn{3}{|c|}{$R_{v}(l)$ залежність не встановлен } & \\
\hline
\end{tabular}
коефіцієнтів $\mathbf{R}_{\mathrm{v}}$ оцінки компонентів фітомаси

Примітка: "st- деревина стовбура, $k-$ кора стовбура, $g-$ гілки, $l-$ листя (хвоя).

Використання алгоритму розрахунку, описаного вище, дало змогу отримати такі дані (табл. 2).

\begin{tabular}{|c|c|c|c|c|c|c|}
\hline \multirow{2}{*}{$\begin{array}{c}\text { Лісорослинна } \\
\text { зона, рік обліку }\end{array}$} & \multirow{2}{*}{$\begin{array}{c}\text { Площа вкритих лісовою } \\
\text { рослинністю лісових } \\
\text { ділянок, тис. га } \\
\end{array}$} & \multirow{2}{*}{$\begin{array}{l}\text { Запас стовбурової } \\
\text { деревини, млн м }^{3}\end{array}$} & \multicolumn{2}{|c|}{ Фітомаса } & \multicolumn{2}{|c|}{ Вуглець } \\
\hline & & & МлН т & $\begin{array}{l}\text { щільність, } \\
\kappa \Gamma \cdot\left(\mathrm{M}^{2}\right)^{-1} \\
\end{array}$ & МлН т & $\begin{array}{c}\text { щільність, } \\
\kappa \Gamma \cdot\left(\mathrm{M}^{2}\right)^{-1} \\
\end{array}$ \\
\hline \multicolumn{7}{|c|}{ на 01.01.1978 p. } \\
\hline Полісся & 290,1 & 41,0 & 26,2812 & 9,1 & 13,0247 & 4,5 \\
\hline Лісостеп & 124,3 & 17,3 & 12,8130 & 10,3 & 6,3645 & 5,1 \\
\hline Разом & 414,4 & 58,3 & 38,8627 & 9,4 & 19,2695 & 4,6 \\
\hline \multicolumn{7}{|c|}{ на 01.01.1983 р. } \\
\hline Полісся & 292,9 & 55,0 & 35,0796 & 12,0 & 17,3852 & 5,9 \\
\hline Лісостеп & 129,4 & 23,6 & 17,1138 & 13,2 & 8,5043 & 6,6 \\
\hline Разом & 422,3 & 78,7 & 51,9528 & 12,3 & 25,7708 & 6,1 \\
\hline \multicolumn{7}{|c|}{ на 01.01.1988 р. } \\
\hline Полісся & 290,7 & 54,1 & 34,4823 & 11,9 & 17,0896 & 5,9 \\
\hline Лісостеп & 130,7 & 23,2 & 16,7674 & 12,8 & 8,3315 & 6,4 \\
\hline Разом & 421,3 & 77,3 & 50,9744 & 12,1 & 25,7708 & 6,0 \\
\hline \multicolumn{7}{|c|}{ на 01.01.1996 р. } \\
\hline Полісся & 234,5 & 53,7 & 34,2351 & 14,6 & 16,9961 & 7,2 \\
\hline Лісостеп & 131,8 & 29,8 & 21,6717 & 16,4 & 10,7805 & 8,2 \\
\hline Разом & 365,6 & 83,5 & 55,4832 & 15,1 & 27,5654 & 7,5 \\
\hline \multicolumn{7}{|c|}{ на 01.01.2002 р. } \\
\hline Полісся & 212,1 & 53,6 & 33,9596 & 16,0 & 16,8686 & 8,0 \\
\hline Лісостеп & 128,1 & 30,9 & 22,5560 & 17,6 & 11,2244 & 8,8 \\
\hline Разом & 340,2 & 84,5 & 56,1796 & 16,5 & 27,9234 & 8,2 \\
\hline \multicolumn{7}{|c|}{ на 01.01.2011 p. } \\
\hline Полісся & 210,6 & 56,9 & 36,8959 & 17,5 & 18,309 & 8,7 \\
\hline Лісостеп & 144,5 & 36,7 & 26,9901 & 18,7 & 13,4215 & 9,3 \\
\hline Разом & 355,1 & 93,6 & 63,2617 & 17,8 & 31,4159 & 8,8 \\
\hline
\end{tabular}

Табл. 2. Загальна фітомаса та вуглець у лісових насадженнях Київської області

Проаналізувавши дані Київської обл. загалом на 1.01.1978 р., площа вкритих лісовою рослинністю лісо- вих ділянок становила 414,4 тис. га із загальним запасом стовбурової деревини 58,3 млн м³ 
сяг фітомаси дорівнював 38,8627 млн т, у якій було акумульовано 19,2695 млн т вуглецю. Щільність фітомаси та вуглецю на 1 м $^{2}$ вкритих лісовою рослинністю лісових ділянок становила 9,4 кг, 4,6 кг відповідно. Щодо даних за лісорослинними зонами, то площа на Поліссі становила 290,1 тис. га із запасом стовбурової деревини 41,0 млн м ${ }^{3}$, а обсяг фітомаси дорівнював 26,2812 млн т, у якій було акумульовано 13,0247 млн т вуглецю. Щільність фітомаси на 1 м $^{2}$ вкритих лісовою рослинністю лісових ділянок становила 9,1 кг, а щільність вуглецю 4,5 кг. У Лісостепу площа - 124,3 тис. га із загальним запасом стовбурової деревини 17,3 млн м ${ }^{3}$, обсяг фітомаси становив 12,8130 млн т, у якій акумульовано 6,3645 млн т вуглецю. Щільність фітомаси та вуглецю 10,3 кг $\left(\mathrm{M}^{2}\right)^{-1}, 5,1$ кг $\left(\mathrm{м}^{2}\right)^{-1}$ відповідно. За 33 роки площа лісових насаджень Київської обл. зменшилась на 59,3 тис. га (14,3\%), це пов'язано із територіальними та адміністративними змінами, а запас навпаки збільшився на 35,3 млн м ${ }^{3}(60,5 \%)$, завдяки збільшенню запасу стиглих і перестиглих насаджень. Відповідно збільшився обсяг фітомаси насаджень на 24,399 млн т $(62,8 \%)$ i акумульованого в ній вуглецю на 12,1464 млн т, а також зросла їхня щільність. Аналізуючи дані за лісорослинними зонами, спостерігаємо таку тенденцію. У зоні Полісся площа зменшилась на 79,5 тис. га $(27,4 \%)$, а в зоні Лісостепу навпаки збільшилась на 20,2 тис. га $(16,3 \%)$. Водночас зовсім інша тенденція відбувається щодо інших показників, запасу, фітомаси та вуглецю, вони навпаки збільшились. Запас стовбурової деревини в зоні Полісся збільшився на 15,9 млн м ${ }^{3}$ (38,8 \%), в Лісостепу - на 19,4 млн м м $^{3}(112,1 \%)$. Фітомаса - на 10,6 млн т (40,4\%) в Поліссі і 14,2 млн т (110,6\%) - в Лісостепу. Щільність фітомаси та вуглецю в Поліссі збільшилась на 92,3 \%, 93,3 \% в Лісостепу - на 81,6 \%, $82,4 \%$ відповідно.

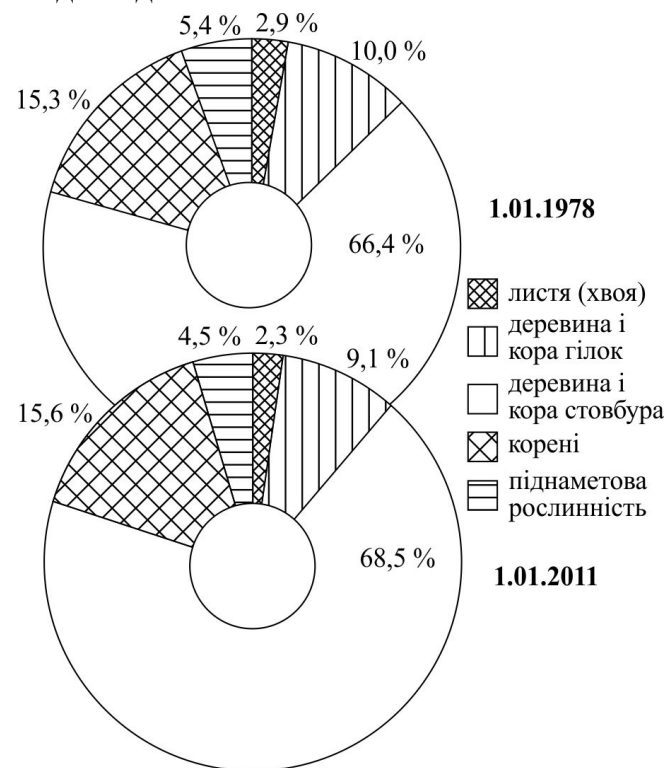

Рис. 1. Зміна структури компонентів фітомаси насаджень Київської області за роками досліджень

Зміну структури компонентів фітомаси насаджень Київської обл. за роками досліджень відображено на рис. 1. 3 цього рисунку видно, що більша частка у структурі фітомаси належить деревині і корі стовбура. Якщо дивитись у загальній структурі насаджень, то вміст цього компонента зріс на $2,1 \%$ за досліджуваний період, тобто від 66,4 до 68,5\%. Відповідно зменши- лась частка деревини і кори гілок від 10,0 до 9,1\%, листя - від 2,9 до 2,3\% та піднаметова рослинність - від 5,4 до 4,5\%. Така зміна структури фітомаси цілком закономірна, оскільки за досліджуваний період у Київській обл. зменшилась площа молодняків та збільшилась площа стиглих та перестиглих насаджень, які мають більший запас стовбурової деревини.

Динаміку щільності фітомаси та депонованого в ній вуглецю впродовж досліджуваного періоду можна спостерігати на рис. 2. Аналізуючи криві, можна стверджувати, що впродовж досліджуваного періоду щільність фітомаси та депонованого в ній вуглецю в насадженнях Київської обл. збільшилась в 1,9 раза. В основному це відбулося внаслідок збільшення середнього запасу на 1 га та перерозподілу у віковій структурі лісових насаджень.

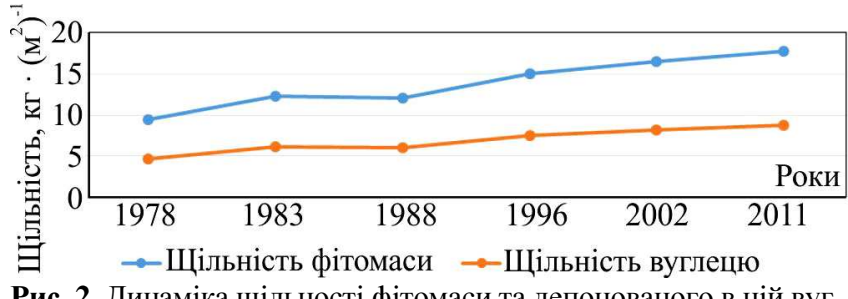

Рис. 2. Динаміка щільності фітомаси та депонованого в ній вуглецю в насадженнях Київської області

На рис. 3 графічно показано динаміку фітомаси насаджень упродовж досліджуваного періоду за лісорослинними зонами Київської обл. Аналізуючи цей рисунок можна зробити висновок, що впродовж 19782011 рр. у Київській обл. за лісорослинними зонами загальна фітомаса насаджень збільшилась істотно. На сьогодні найбільша кількість фітомаси зосереджена на Поліссі - 36,8959 млн т.

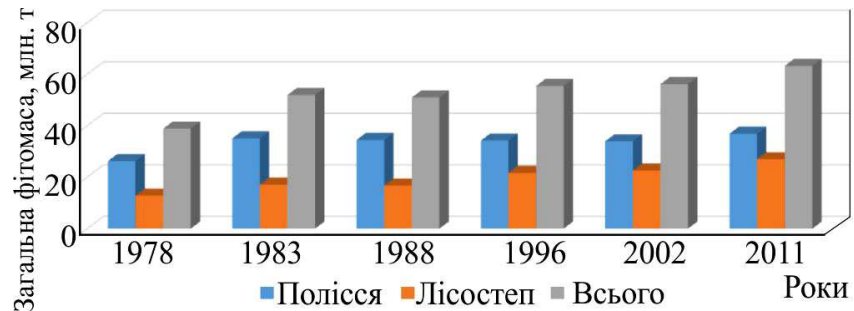

Рис. 3. Динаміка фітомаси за лісорослинними зонами в насадженнях Київської області

У лісостеповій зоні дещо менше 26,9901 млн т. Це пов'язано із площею та запасом стовбурової деревини. Так, площа укритих лісовою рослинністю лісових ділянок Полісся становить 210,6 тис. га, запас - 56,9 млн м ${ }^{3}$. Лісостепова зона Київщини становить 144,5 тис. га, запас - 36,7 млн м ${ }^{3}$. Загалом через те, що нині в лісах області переважають середньовікові насадження, які найсильніше продукують фітомасу, її запаси зросли на 24,399 млн т. Відповідно на Поліссі - в 10,6147 млн т, у Лісостепу - 14,1771 млн т.

Висновки. Ведення лісового господарства на цей час повинно бути орієнтоване на комплексне використання всього біологічного продукту, що виробляє ліс. Це свідчить про актуальність оцінки продуктивності деревостанів.

Під час аналізу визначено позитивну динаміку кількісних показників збільшення щільності фітомаси та вуглецю в насадженнях Київської обл., яка зросла відповідно на 8,4-4,2 кг·( $\left.\mathrm{m}^{2}\right)^{-1}$. За досліджуваний період відбулося збільшення фітомаси в 1,6 раза. Відповідно в 
лісорослинних зонах Полісся та Лісостеп у 1,4-2,1 раза. Тобто на 1.01.2011 р. загальний обсяг фітомаси області становив 63,2617 млн т, де було акумульовано 31,4159 млн т вуглецю.

Середня щільність фітомаси на $1 \mathrm{~m}^{2}$ вкритих лісовою рослинністю лісових ділянок області становить 17,8 кг, вуглецю - 8,8 кг. У лісорослинній зоні Полісся щільність фітомаси становить 17,5 кг $\left(\mathrm{M}^{2}\right)^{-1}$, вуглецю 8,7 кг·( $\left(\mathrm{M}^{2}\right)^{-1}$. Щільність фітомаси лісостепової зони 18,7 кг $\left(\mathrm{M}^{2}\right)^{-1}$, вуглецю - 9,3 кг·( $\left(\mathrm{м}^{2}\right)^{-1}$. Що майже на $25 \%$ більше порівняно з середнім показником для лісів України (13,7 і 6,6 кг·( $\left.\left(\mathrm{м}^{2}\right)^{-1}\right)$ відповідно (Lakyda, et al., 2007, 2010). Отже, на підставі наведених даних можна стверджувати, що насадження Київської обл. є продуктивними, мають значний ресурсний потенціал, $є$ досить потужним регулятором кліматичних процесів, тобто депонують вуглекислий газ та виділяють кисень і $є$ надійним джерелом вирішення проблеми зміни клімату та збереження довкілля.

\section{Перелік використаних джерел}

Botkin, D. B., \& Simpson, L. G. (1990). Biomass of the North American Boreal Forest. Biogeochemistry, 9(2), 161-174.

Lakida, P. (1996). Forest Phytomass Estimation for Ukraine. Laxenburg: IIAS A, $75 \mathrm{p}$.

Lakida, P. I. (1988). Model dinamiki produktivnosti sosniakov po komponentam nadzemnoi biomassy. Primenenie mini EVM $v$ nauchnykh issledovaniiakh $i v$ uchebnom protcesse vuzov: tezisy dokl. nauch. konf. (pp. 15-16). Kaunas. [In Russian].

Lakida, P. I. (1990). Modelirovanie dinamiki komponentov biomassy drevostoev. Sovershenstvovanie vedeniia khoziaistva $v$ lesakh Ukrainy i Moldavii: tezisy dokl. resp. nauch.-tekhn. konf. (pp. 132-134). Kyiv: USKhA. [In Russian].

Lakida, P. I., Belous, A. M., Vasilishin, R. D., \& Zibtcev, S. V. (2010). Bioproduktivnost i energeticheskii potentcial lesov Ukrainy. Materialy Mezhdunarodnoi nauchno-prakticheskoi konferentcii, posviashhennoi 80-letiiu Instituta lesa NAN Belarusi, November, 17-19, (pp. 53-56). Gomel: Institut lesa NAN Belarusi. [In Russian].

Lakyda, P. I. (1996). Produktyvnist lisovykh nasadzhen Ukrainy za komponentamy nadzemnoi fitomasy. Doctoral Dissertation for Agricultural Sciences (06.03.02 - Forest Management and Forest Taxation). Kyiv, 304 p. [In Ukrainian].

Lakyda, P. I., Mazur, O. V., Vasylyshyn, O. M., et al. (2007). Metodychni aspekty monitorynhu vuhletsiu $\mathrm{v}$ lisostanakh Ukrainy. Pryrodno-resursnyi kompleks Zakhidnoho Polissia: istoriia, stan, perspektyvy rozvytku: Mater. nauk.-prakt. konf., Berezne, April 2526, 2007. (pp. 45-46). Berezne: NSI. [In Ukrainian].

Madgwick, H. A. I. (1970). Biomass and productivity models of forest canopies. Ekological studies: Analysis and synthesis, 4, 47-54; Heidelberg, Berlin: Springer Verlag. Y. 1: Analysis of temperate forest ecosystems.

Satto, T., \& Madgwick, H. A. I. (1982). Forest biomass. The Hagel etc.: M. Nijhoff; Dr. W. Junk Publ., 152 p.

Usoltcev, V. A. (1984). O tochnosti regressionnoi otcenki fitomassy drevostoev. Vesnik selskokhoziaistvennoi nauki Kazakhstana, 9, 77-83. [In Russian].

Usoltcev, V. A. (1985a). Modelirovanie struktury i dinamiki fitomassy drevostoev. Krasnoyarsk: Izd-vo Krasnoiarskogo un-ta, 192 p. [In Russian].

Usoltcev, V. A. (1985b). Produktivnost i struktura fitomassy drevostoev. Abstract of doctoral Dissertation for Agricultural Sciences (06.03.02 - Forest Management and Forest Taxation). Kyiv, 46 p. [In Russian].

Separated subdivision of NULES of Ukraine "Boyarka College of Ecology and Natural Resources", Boyarka, Ukraine

\section{DYNAMICS OF FOREST BIOPRODUCTIVITY IN THE KYIV REGION}

The urgency of research on bioproductivity of plantings by phytomass components has long gone beyond the regional problem and acquired a global character. It is believed that due to the improvement of forest reproduction and optimization of the age structure of plantations, additional afforestation of areas it will be possible to move part of $\mathrm{CO}_{2}$ from the atmosphere to the phytomass. In order to obtain comprehensive results that reflect the estimation of bioproductivity by components of phytomass of the main forest species of the Kyiv region, methodological principles are used as the basis for the conducted researches. The results of simulation of components of phytomass of main forest species of the Kiev region are presented. It has been established that the principle of constructing models for assessing the bioproductivity of forest stands of the main forest species in the region based on the components of the above-ground phytomass, which consists in establishing their multifactorial dependencies, depends on the main taxing attributes of plantations, which are indicated in the forest cadastre data. Regression analysis has shown that the most suitable in terms of accuracy and practicality is a two-factor model of the dependence of the main components of phytomass planting, in which the factors involved planting age and bonion class. Plants of the Kiev region are located in two forest areas. During the analysis, the positive dynamics of quantitative indicators of increasing the density of phytomass and carbon in plantations of the Kiev region was determined, which increased by $8.4-4.2 \mathrm{~kg} \cdot\left(\mathrm{m}^{2}\right)^{-1}$, respectively. During the study period there was an increase in phytomass in 1,6 times. Accordingly, in the forest areas Polissya and Forest-steppe in 1.4-2.1 times. Forest plantations have a great influence on the formation of the environment and can affect factors such as temperature and humidity of the planet. The role of the forest can not be assessed as something unambiguous, since this resource is used in a variety of industries. Therefore, the plantations of the Kyiv region have important economic, ecological and social significance, perform important protective and protective functions and are highly productive.

Keywords: tree plant; average stock; forestry; forest areas; phytomass density; carbon density; conversion factors. 